\title{
THE WAYS OF SAINT JAMES IN TRÁS-OS-MONTES AND ALTO DOURO AS AN EXAMPLE OF SOFT TOURISM IN RURAL AREAS
}

Pedro Azevedo ${ }^{1}$

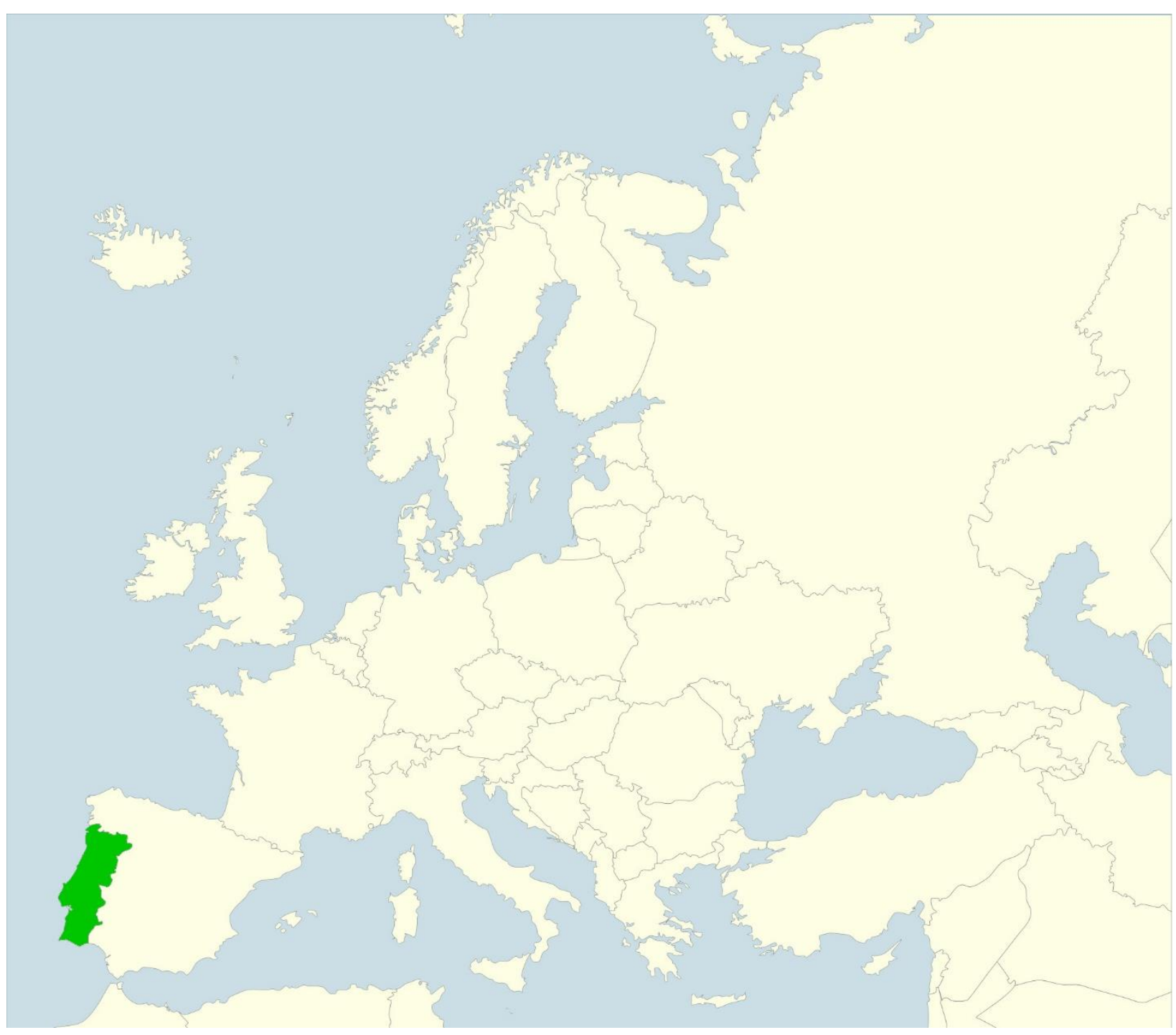

${ }^{1}$ Pedro Ricardo Coelho de Azevedo, Degree in History and Master in Heritage and Cultural Tourism by the University of Minho, Researcher at The Centre for Transdisciplinary Development Studies of University of Trás-os-Montes and Alto Douro, Vila Real, Portugal; e-mail: pedrodosrc@gmail.com, ORCID: 0000-0001-9077-9406 
Abstract: The objective of this study is to demonstrate the importance of the existing Ways of Saint James in Trás-os-Montes and Alto Douro, in the northern interior of Portugal, and that being integrated in soft tourism, can constitute a mechanism that allows the revitalization of rural areas, especially the sparsely populated areas, because it allows a series of benefits such as the increase of tourists and pilgrims, the creation of new services, among other structures, thus boosting tourism development. Above all, these Paths linked to soft tourism, allow us to highlight the predominance of tourism linked to nature tourism and slow mobility. In order to carry out this study, the methodology used will be based on interviews to tourists and pilgrims in order to obtain testimonies that can characterise the impact of the Ways themselves on rural territories.

Keywords: rural territories; rural development; Ways of Saint James; soft tourism; communities

Resumen: El objetivo de este estudio es demostrar la importancia de los Caminos de Santiago existentes en Trás-os-Montes y Alto Douro, en el interior norte de Portugal, y que al estar integrados en el soft tourism, pueden constituir un mecanismo que permite la revitalización de las zonas rurales, especialmente las poco pobladas, ya que permite una serie de beneficios como el aumento de turistas y peregrinos, la creación de nuevos servicios, entre otras estructuras, impulsando así el desarrollo turístico. Sobre todo, estos Caminos vinculados al soft tourism, permiten destacar el predominio del turismo vinculado al turismo de naturaleza y a la movilidad lenta. Para la realización de este estudio, la metodología utilizada se basará en entrevistas a turistas y peregrinos con el fin de obtener testimonios que permitan caracterizar el impacto de los propios Caminos en los territorios rurales.

Palabras clave: territorios rurales; desarrollo rural; Caminos de Santiago; soft tourism; comunidades

\section{Highlights:}

- This study shows that the conversion of the Ways of Saint James located in the region of Trás-os-Montes and Alto Douro into tourist-cultural itineraries allows them to be inserted in the phenomenon of soft tourism, being combined with the environmental component, the local communities, the landscapes and the heritage;

- The tourist-pilgrims who travel along these paths, taking into account their multiple motivations, promote the development and dynamisation not only of the Ways themselves but also of the local territories and local communities crossed;

- These are paths travelled with soft means of transport: walking and cycling;

- It is clear that the inclusion of these Ways of Saint James that cross the region in soft tourism of environmental and sustainable nature occurs due to two factors: the inexistence of mass tourism and the routes being implemented in predominantly rural areas. 


\section{Introduction}

Rural territories are generally considered peripheral to urban areas and present internal and transversal problems to other regions, such as population decline, lack of services, among other reasons. To promote the development of rural areas, it is essential to identify the specific resources existing in these territories (Varga, 2015).

In this sense, soft tourism, understood as a tourism based on the valorisation of the potential of the local territory (Krippendorf, 1982), has served as a clear bet of rural territories to boost tourism and territorial dynamisation. In fact, soft tourism promotes the local economy, endogenous heritage and traditions, besides being associated with nature tourism.

In recent years, the growing number of tourists and pilgrims that travel the various Ways of Saint James, part of the soft tourism typology, allows them to play a key role in the process of development and construction of the territory, creating various opportunities for development of the territories where these routes pass, especially the rural towns and communities. In historical terms, the Ways have shaped towns, villages and territories over the centuries. The place, the landscape, the history, the tradition and the build around the paths (Pérez, 2015: 138), as well as the routes themselves, constitute the axes that enhance the development of the territory.

The Trás-os-Montes and Alto Douro region has numerous rural communities, understood as small settlement units that are marked by their agricultural component. The conversion of the Ways into tourist-cultural routes presents itself as a decisive mechanism to promote development at various levels (Olsen \& Trono, 2018), allowing to create flows and new tourist dynamics, referring to the transcendent dimension of development, i.e., the emergence of a multilevel development, i.e., in economic, territorial, environmental, among others. As it will be shown, the Ways makes it possible to reduce asymmetries, since it is a continuous development that ends up covering most of the territory. The respective valorisation of the Ways allows the development of these villages inserted along the pilgrimage routes, where the development of the villages around the Ways is part of a transversal phenomenon in several European countries.

The growing tourism valorisation of the Ways of Saint James has also had repercussions on the development of the villages in several ways. The main consequence is the tourist development of these villages, where structures and new services are created, allowing a new vitality of these places. As will be shown, the prospects for development are mostly based on an economic dimension and a sustainable dimension.

The structure of this text is composed as follows: the first part will address the geographical and historical contextualization of these pilgrimage routes existing in Trás-os-Montes and Alto Douro, while in the second part a theoretical framework of the concepts of soft tourism and rural development will be carried out, to then analyse the development around the Ways. Consecutively, in the fourth part, the methodology used in this study will be explained, while the fifth section will demonstrate the results obtained based on interviews with tourists and pilgrims, as well as with tourism technicians. Finally, in the last part, the final considerations about the importance of the Ways of St. James for the development of rural territories and its insertion in soft tourism will be demonstrated.

\section{Ways of Saint James: Pilgrimage routes in Trás-os-Montes and Alto Douro}

\subsection{Territorial context}

The region of Trás-os-Montes and Alto Douro is localised in the interior north of Portugal and meets itself divided in statistical terms in three NUTs, of level III (NUTS - Nomenclatures of Territorial Units): Terras de Trás-os-Montes, Douro and Alto Tâmega, prefixing a total of 34 municipalities, as it is demonstrated in table 1. In geographic terms, the region meets delimited to the North and in the East by Spain, to the West by the sub-regions of Alto Minho, Ave, and Tâmega and Sousa; and to the South by the sub-regions of Beiras and Serra de Estrela, and Dão-Lafões. 
Tab 1. Socio-territorial characterization of Trás-os-Montes and Alto Douro. Source: self-elaboration and National Statistical Institute (INE, 2020)

\begin{tabular}{|l|c|c|c|}
\hline \multicolumn{1}{|c|}{ NUT / Sub-region } & $\begin{array}{c}\text { Number of } \\
\text { municipalities }\end{array}$ & $\begin{array}{c}\text { Number of } \\
\text { parishes }\end{array}$ & $\begin{array}{c}\text { Population (in } \\
\text { the year 2011) }\end{array}$ \\
\hline Terras de Trás-os-Montes & 9 & 195 & 117,527 \\
\hline Douro & 19 & 217 & 205,902 \\
\hline Alto Tâmega & 6 & 118 & 94,143 \\
\hline Total & 34 & 530 & 417,572 \\
\hline
\end{tabular}

Most of these municipalities can be inserted in the concept of rural territory regarding a set of statistical indicators, namely population, institutional, social, economic and environmental indicators. Next, some indicators will be presented that allow us to sustain that the territory of Trásos-Montes and Alto Douro is characterized by being a mostly rural territory.

In terms of enterprises and economic activities in the region, it is notorious that the region that concentrates the biggest number of activities is the NUT-III Douro, followed by Trás-os-Montes and finally Alto Tâmega, as we can see in Table 2.

Tab 2. Number of enterprises by economic activities and sub-region. Source: Empresas não financeiras: total e por sector de actividad económica. Base de Dados Portugal Contemporâneo.

\begin{tabular}{|c|c|c|c|}
\hline NUT - Sub-region & $\begin{array}{c}\text { Agriculture, Livestock, } \\
\text { Hunting, Forestry and } \\
\text { Fishing (in the year 2018) }\end{array}$ & $\begin{array}{c}\text { Trade (in the } \\
\text { year 2018) }\end{array}$ & $\begin{array}{c}\text { Hotels, restaurants } \\
\text { and similar (in the } \\
\text { year 2018) }\end{array}$ \\
\hline Alto Tâmega & 5,390 & 1,888 & 1,016 \\
\hline Douro & 15,068 & 8,866 & 2,923 \\
\hline $\begin{array}{c}\text { Terras de Trás-os- } \\
\text { Montes }\end{array}$ & 10,468 & 4,094 & 1,804 \\
\hline Total & 30,926 & 8,188 & 5,743 \\
\hline
\end{tabular}

In view of this, it is visible that the primary sector, i.e. agriculture, assumes great importance in the three NUTs.

In this case and taking into account the aforementioned indicators, the three intermunicipal communities are essentially composed of predominantly rural areas, which are based on the parishes not classified as "Predominantly Urban Area" nor "Medially Urban Area", according to the Urban Areas Report - TIPAU (TIPAU, 2014; INE 2020), as illustrated in Figure 1.

Despite the predominance of places considered totally rural, it is important to refer that there are also urban places such as the cities of Vila Real, Chaves and Bragança, among others, as well as places with semi-urban characteristics. 


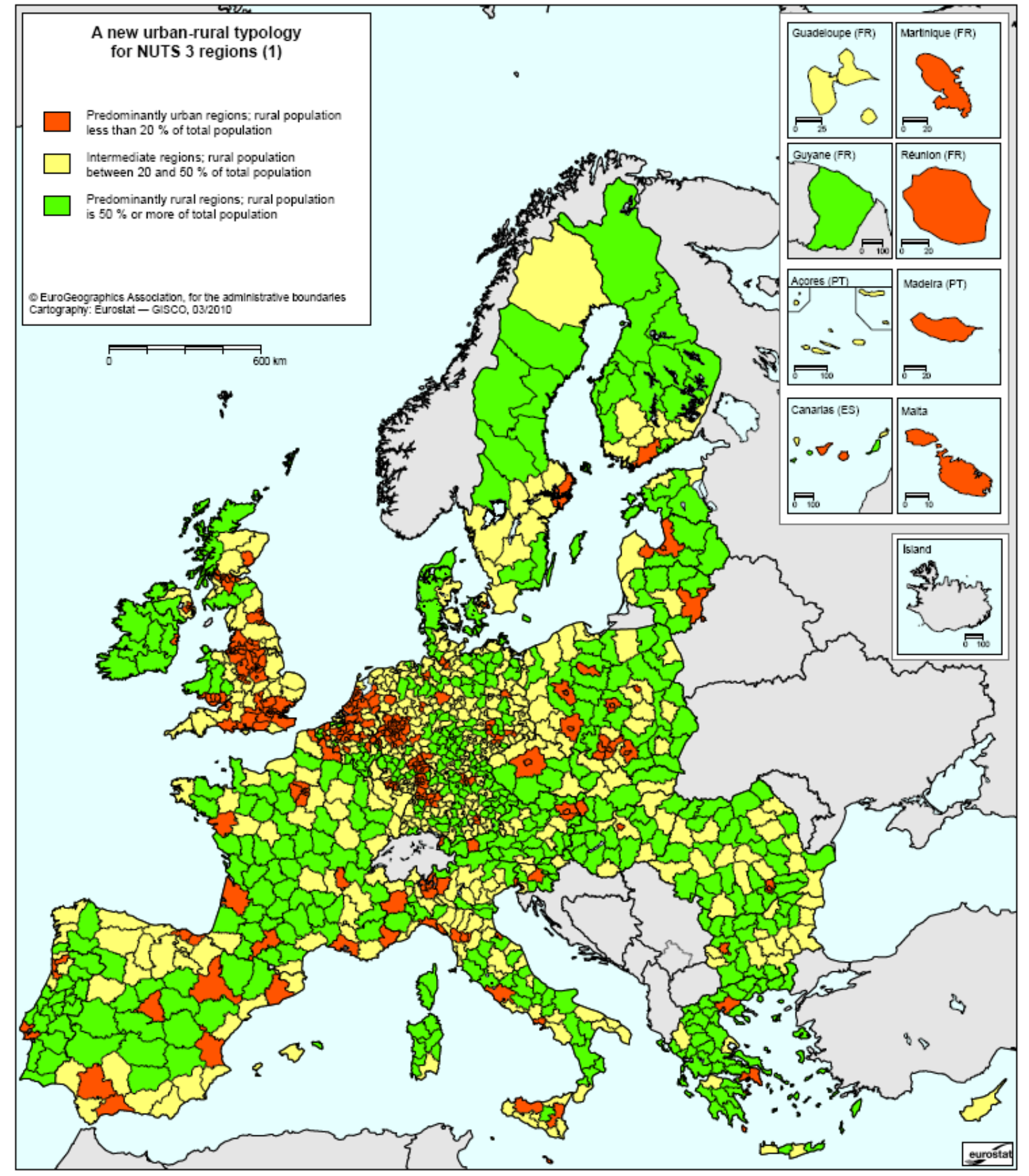

(1) This typology is based on a definition of urban and rural $1 \mathrm{~km}^{2}$ grid cells. Urban grid cells fulfil two conditions: 1) a population density of at least 300 inhabitants per $\mathrm{km}^{2}$ and 2) a minimum population of 5000 inhabitants in contiguous cells above the density threshold. The other cells are considered rural. Thresholds for the typology. $50 \%$ and $20 \%$ of the regional population in rural grid cells.

For Madeira, Açores and the French outermost regions, the population grid is not available. As a result, this typology uses the OECD classification for these regions.

Fig 1. Urban-rural typology by NUTS III in the European Union. Source: EUROSTAT 


\subsection{Analysis of the Ways of Saint James}

The Ways of Saint James have seen a marked growth, especially since the 2000s, setting a new record in 2019 with the arrival of 350,000 pilgrims to Santiago de Compostela through the various Ways. The French Way presents itself as the most travelled route by pilgrims, while the Portuguese Way is the second most travelled, as shown in figure 2.

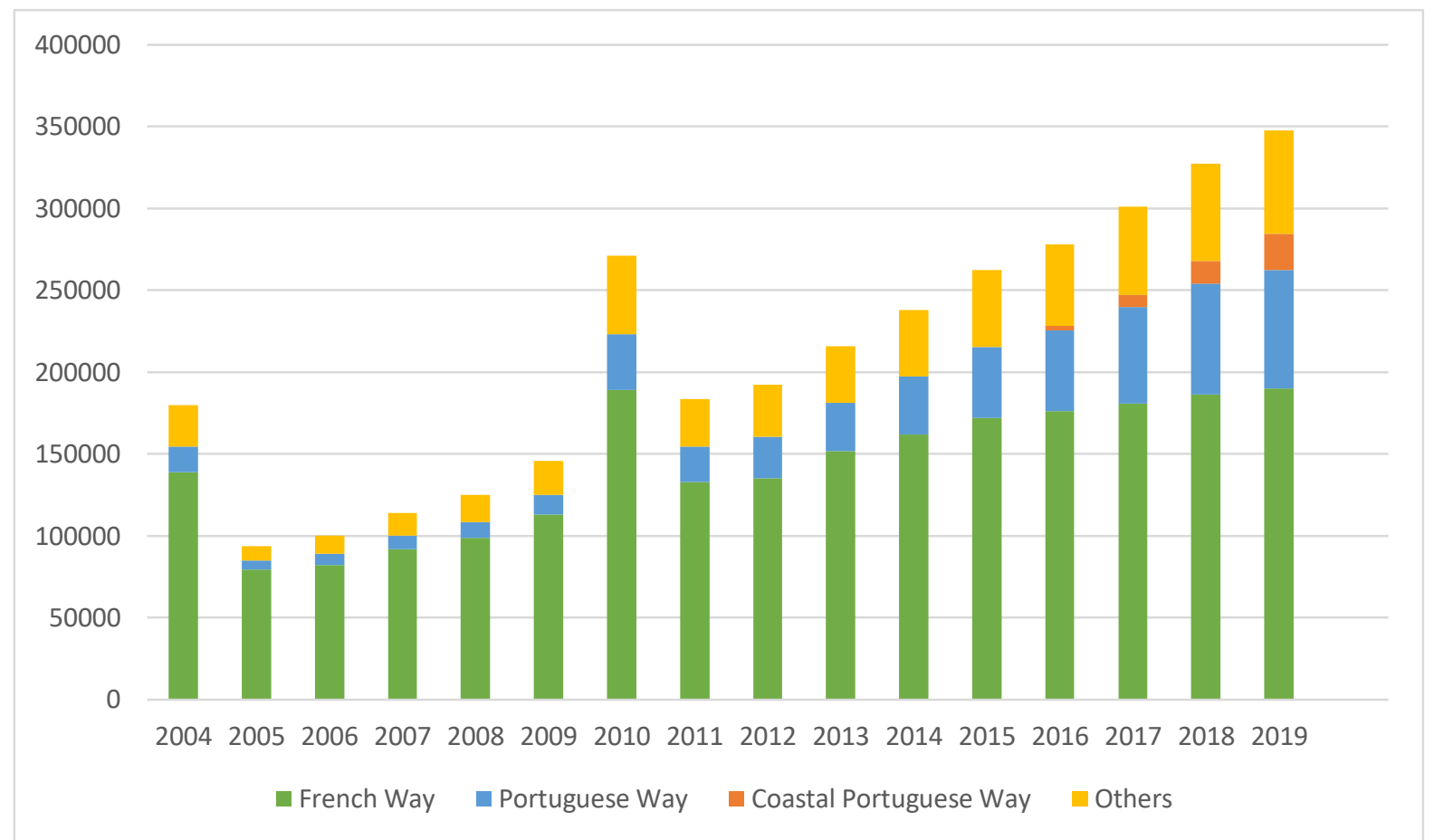

Fig 2. Official statistics of pilgrims arriving at Santiago de Compostela via the various Ways. Source: Pilgrim's Office of Santiago de Compostela Cathedral. Available at: https://oficinadelperegrino.com/

The current pilgrimages lose their religious sense when they come into contact with tourism, since the Ways are not only travelled with religious motivations but also in a multi-motivational way. In this sense, there is a deep connection between the concepts of tourist and pilgrim, leading to the emergence of the term "tourist-pilgrim", whose designation we adopt in this study.

In recent years, the existing Ways of Saint James in Trás-os-Montes and Alto Douro, such as the Portuguese Inner Way to Santiago de Compostela (PIWSC), Portuguese Silver Way, Torres Way, Terras de Basto Way and Coração D'Ouro Way, illustrated in figure 3, have also registered an increase of tourist-pilgrims, much due to the processes of revitalisation they have been undergoing.

Regarding the number of tourist-pilgrims that travel the Ways of Saint James in the region of Trásos-Montes and Alto Douro, the Pilgrim's Office does not count them and for this reason does not provide official data for these routes. The most recent data are only relative to the PIWSC and are only provided by local authorities such as City Councils and tourist offices. This data shows that the PIWSC was walked by 338 people in 2017 and by 308 people in 2018, and there is no data for the years 2019 and 2020. It is assumed that the remaining routes register an increasing flow of tourist-pilgrims. At the same time, this situation demonstrates a reduced tourist massification and the cultural intimacy that these routes provide is a pilgrimage and tourist experience (Eixo Atlántico, 2016; Pereiro, 2017). 


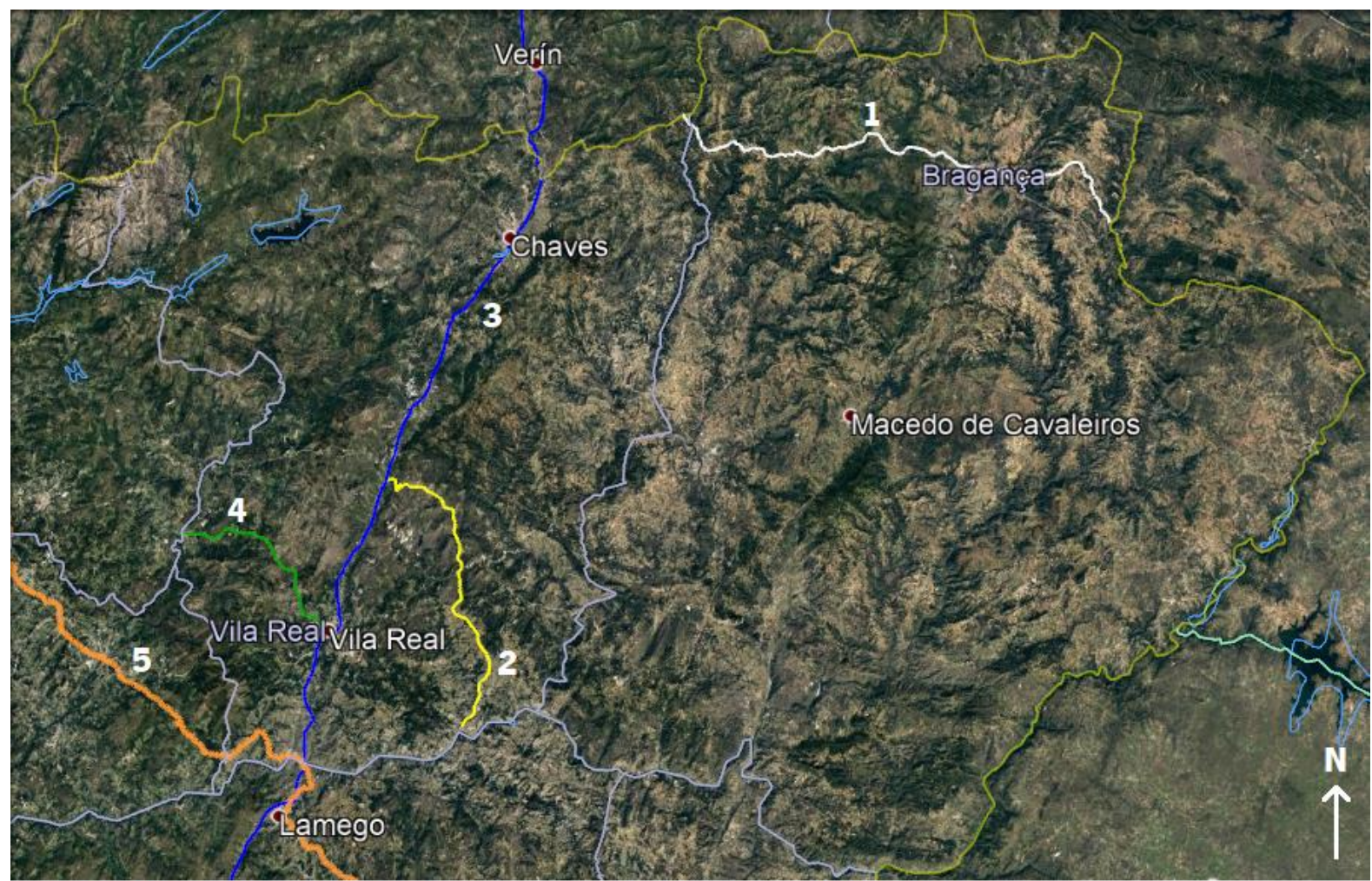

\section{1 - The Portuguese Silver Way \\ 3 - PIWSC \\ 5 - Torres Way}

2 - Coração D'Ouro Way

4 - Terrras de Basto Way

Fig 3. Ways of Saint James Trás-os-Montes and Alto Douro. Source: self-elaboration

These Ways besides having remote origins, based on ancient ways of Roman and medieval origin (Almeida, 1968), the PIWSC, the Torres Way and the Portuguese Silver Way, are transnational pilgrimage routes between Portugal and Spain. Besides, they have a set of characteristics that make them different from the other Pilgrims' Ways of Santiago:

a) They are of high historical and heritage interest, especially numerous heritage assets linked to the cult of Saint James;

b) They cross territories with important natural and environmental features: the PIWSC and the Torres Way cross the Alto Douro Wine Region, a UNESCO world heritage site; the PIWSC also passes close to the Alvão Natural Park; and the Portuguese Silver crosses the Montesinho Natural Park; which are environmentally protected areas;

c) They cross mostly rural territories;

d) Other environmental and rural aspects: the itineraries go through rural villages, the so called "Villages of Portugal", such as the villages of Favaios, Lamas de Olo, among others;

e) The PIWSC presents a singularity in relation to other Pilgrims' Ways of Saint James, which has to do with the fact that it is a two-way street, that is, pilgrims can use this itinerary to reach the sanctuary of Fátima, the route being signposted with blue arrows.

\subsection{Soft tourism and the Ways of Saint James: a form of rural development}

The term "soft tourism" is a contemporary concept which emerged in Central Europe in the 1980s. It is characterized by being inverse to the concept of hard tourism and is linked to rural tourism, having adjacent values linked to sustainability, nature preservation, landscape, and agriculture, among other aspects (Guiver \& McGrath, 2017). The combination of pilgrimages with tourism motivations meets these values, where they seek to have different activities locally, obtain local products, maximizing the potential of rural territories (Oliver \& Jenkins, 2003). 
Soft tourism encourages a greater interaction within the local economy than traditional or hard tourism, making visitors spend in the local area and generating more beneficial effects in rural economies and consequently, allowing a development of these territories (Slee et al, 1995; Slee et al, 1997).

According to Krippendorf, each region should find a development driver, betting on the potential of the local territory (1982), resorting to various strategies, where the bet on soft tourism is a prime example, as a strategy to promote regional and local development (Sousa, 2014: 33).

In addition, soft tourism generally comprises small-scale, locally-owned businesses based on resources that are identitary to the local area, such as the natural environment and local products, and that are embedded in the local economy, examples being accommodation, local craft and food businesses (Snowdown et al, 2000: 143). Among other aspects, the growing number of touristpilgrims walking the Ways of Saint James has led to the reappearance of craft activities in these places; it has led to the revitalisation of museums and the emergence of new complementary services, which provide alternative activities with the aim of making tourist-pilgrims stay longer in these places (Duarte, 2016: 53).

Many rural areas have launched actions to enhance and promote their endogenous resources (tangible and intangible heritage resources, landscape resources, among others) in order to achieve sustainable development and adapt to soft tourism (Ledo et al, 2007), and this situation is transversal to Spain and Portugal.

The term rural is broadly defined as a spatial or territorial concept that presupposes a plurality of rural areas (Sharpley \& Sharpley, 1997; Figueiredo, 2011). The concept of rural area may receive several designations: rural settlement, rural community or commonly, village. The designation rural area has several theoretical frameworks from various authors (Bambi et al, 2019; Terluin, 2003), and is also understood as a territorial unit that is necessarily surrounded by one or more small to medium-sized towns. It also has other characteristics of its own and identities such as: the economy of this region is based on mainly agricultural activities, its population density is low, it faces depopulation, lack of resources and financial innovations, peripheral position, lack of employment opportunities and high quality services, among others. It is not a watertight concept, i.e. it can be defined in different ways and from different perspectives.

Both at European and national level, rural territories are considered peripheral and consequently, considered to be more backward. This situation occurs due to several factors such as demographic decline, rural exodus, the absence of job-generating companies, the inefficiency of public policies, among other reasons. Many times, these factors are transversal to other national and European regions and are generated by external realities. However, Varga deconstructs this perspective by stating that all regions considered to be lagging behind have growth and development potential (2015: 13).

To promote the development of rural areas, it is essential to identify the specific resources existing in these territories, such as heritage and other potentialities, and which can be exploited locally (Oliveira, 2012: 86; Seravalli, 2015: 10-11). Heritage assets just like the Pathways themselves, constitute a cultural resource belonging to the territory and that are identitary to the communities (Cohen, 1993). The growing inclusion of heritage in the dynamics of economic, territorial and social development, allows advocating development initiatives for rural territories that until now felt some weaknesses, particularly in the tourism area.

\subsection{Theoretical contextualisation of the development around the Ways of Saint James}

The literature review shows transformation of the Ways into a tourism product, which gives it a broadly economic dimension, allowing the creation of new services that generate revenue and create jobs in these regions, and this view is reinforced by several authors (Roget et al, 2018; Cova et al, 2019; d'Entremont \& Lerga, 2019). Tourism has a high potential for the development of depressed territories, including rural areas (Eusebio et al, 2014). Moreover, rural development involves the development of people and places (Dentinho \& Rodrigues, 2007). In the case of PIWSC, there are some recent studies that analyse the contributions of this route on local development (Pereiro, 2019; Freitas et al, 2021). 
In fact, the Ways located in the interior north of Portugal cross territories that in recent decades have been experiencing processes of abandonment and rural impoverishment (Lois-González \& Santos, 2014). From the same perspective, these paths allow social and territorial cohesion.

The Ways of Saint James are based on six major development premises, which in turn, enhance the development of the rural territories through which they pass. This situation is explained in the scheme of figure 4.

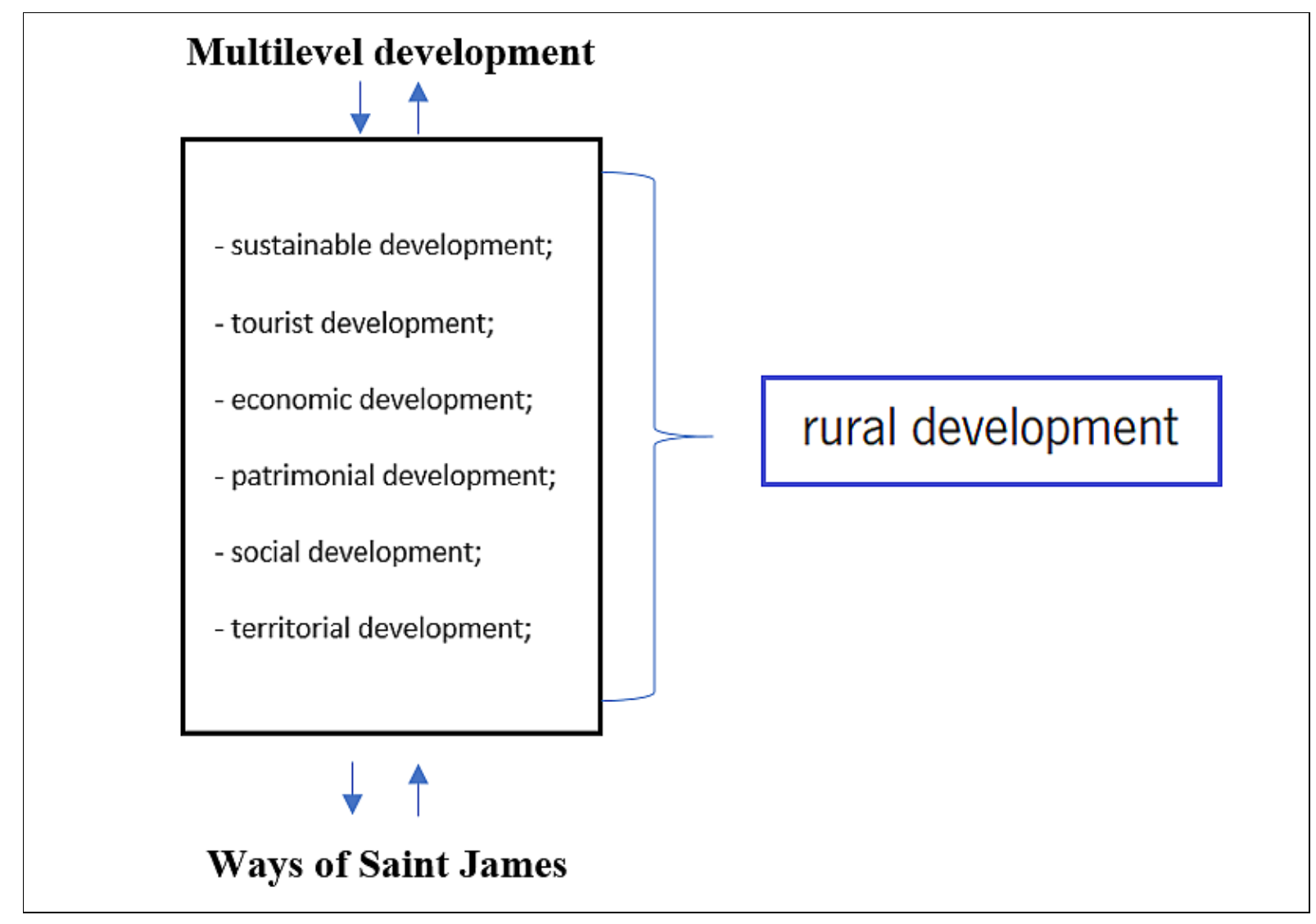

Fig 4. different types of development. Source: self-elaboration

Several authors show that the transformation of the Ways into tourist-cultural routes (Lourens, 2007; Balestrieri \& Congiu, 2017; Murray \& Graham, 1997) reveals to be the primary mechanism that enhances the tourism development of the regions and, in turn, allows rural development. Moreover, the routes propitiate the dynamization of the territory and allow a multilevel development, presenting themselves as transnational routes between Portugal and Spain, more specifically with Galicia (Pereiro, 2019).

In many small territories, these routes have become the main source of income generation, which highlights the transformative capacity of the Ways (Pérez, 2015: 135). In this sense, the multiple Jacobean Ways represent a striking example of how tourism involves a modern and secular metamorphosis of the ancient pilgrimages (Collins-Kreiner, 2010; Lois \& López, 2012). It is important to mention that the development impulses are transferred from the centre of the cities and towns to the rural periphery, that is, because of deeper dynamics and a greater concentration of services and structures that exist in the centres (such as monuments, etc.), which end up benefiting the whole region.

Similarly, the Ways of Saint James currently represent a symbol of European identity and a strategy for local, regional, national and international tourism development (Lois González et al., 2014). The exponential increase of pilgrims walking these routes as tourist routes and the European funds for their revitalisation, has also contributed to the rural settlements and economic growth of these regions (European Commission, 2020). 
As Padin and Blas state, these territories hold a high rurality, present an institutional and functional simplification that allows to boost territorial and heritage development strategies (2015: 1418), with emphasis on the participation of various agents. In this sense, several authors (Bramwell \& Lane, 1999; Merinero, 2011) highlight the importance of the role played by the various agents existing in the territory that assume a central role in driving local development processes.

The valorisation of the Ways cannot be dissociated from a phenomenon of heritagization, this concept being defined by Sánchez-Carretero (2015) and by Ashley (2014) as the processes of valorisation of heritage assets. As Makuc mentions, historical and religious heritage itself can be interpreted as a generator of socioeconomic sustainability and development of many rural areas (2015).

The promotion of the Way is promoted by public and private agents, whose main agents are the State, the municipalities, the parish councils, the local communities and the pilgrims' associations. This view is reinforced by Norman Long, who states that it is necessary to devolve or delegate certain state powers to civic or private organisations at the local and regional level (2005: 183). This view is reinforced by Bjorna and Aarsaether, who state that local government intervention is important to promote entrepreneurship initiatives in rural areas (2010). Any local or regional development initiative should include territorial cooperation within the functional area taking into account the various existing dimensions (functional urban / rural region, cross-border region, transnational / macro-region) (ESPON: 2017, 100).

\section{Methodology}

The methodology used in this research focused essentially on a qualitative approach, where interviews were conducted with tourist-pilgrims, field work was carried out and the same time participant observation, photographic recording and a field diary was used to collect information. At the same time, specific bibliography on the subject was consulted and some statistical indicators were analyzed.

For the application of the interviews, a semi-structured guide was made with previously defined questions, where in a first part, there are questions mainly related to the socio-economic profile, and in a second part, there are questions directly related to the Ways, such as the motivations, expenses and activities performed on the paths. The main questions applied are transcribed below:
a) What were the motivations for doing these Way/s?
b) How much did you spend daily on the Way/s?
c) How much time was spent on the Way/s?
d) What activities and consumption were involved?
e) Would you like to visit the region again?

The option to conduct interviews with tourist-pilgrims who had already walked some of the existing Ways in Trás-os-Montes and Alto Douro proved crucial to understand the development generated by the Ways being walked as a form of soft tourism. Thus, 100 interviews were conducted between the months of August and December 2020, with some interviews being applied face-to-face and others online, due to the difficulty felt in questioning some tourist-pilgrims face-to-face. At the same time, more in-depth interviews were carried out in order to complement the interviews with touristpilgrims, with the tourism technicians of some municipalities that are part of the Ways existing in the territory under study.

Thus, this combination of research methods and techniques was fundamental to obtain an exploratory knowledge which focuses on the contribution of the Ways of Saint James to rural development (Gutiérrez Brito, 2006). 


\section{Analysis of results}

As previously mentioned, interviews were carried out with 100 tourist-pilgrims who had walked one or several existing Pilgrims' Ways to Santiago in Trás-os-Montes and Alto Douro.

Regarding the profile, 76 are men and 24 are women, aged between 19 and 71 . Of these, 84 are Portuguese and 8 are foreigners: 4 Spanish, 2 German and 2 Brazilian.

It is unanimous that the PIWSC is the most travelled way by the interviewees (57) and the second most travelled is the Terras de Basto Way (15). However, 12 interviewees revealed having already travelled more than one of these itineraries.

Tab 3. Number of respondents by Path. Source: self-elaboration

\begin{tabular}{|c|c|c|c|c|c|}
\hline PIWSC & $\begin{array}{c}\text { Portuguese } \\
\text { Silver Way }\end{array}$ & Torres Way & $\begin{array}{c}\text { Terras de } \\
\text { Basto Way }\end{array}$ & $\begin{array}{c}\text { Coração } \\
\text { D'Ouro Way }\end{array}$ & $\begin{array}{c}\text { Various } \\
\text { Ways }\end{array}$ \\
\hline 57 & 3 & 9 & 15 & 4 & 12 \\
\hline
\end{tabular}

The majority of the interviewees have higher education qualifications, a total of 52 . In professional terms, the interviewees are mostly teachers, administrative staff, self-employed workers, and some retired people.

According to the motivations which led them to follow these paths, spiritual motivations predominate with $26 \%$, followed by multiple motivations with $24 \%$. In third place come Adventure motivations, with $14 \%$, and in fourth come leisure motivations with $12 \%$. With less expression are the sports motivations with $8 \%$ and religious motivations with $6 \%$. This situation is shown in figure 5 .

With regard to the time spent doing the Ways, 70 interviewees say that they do the paths between one day and five days, as shown in figure 6 . It should be noted that the fact that the paths are done in one day may indicate that it is done in stages and that there is a return to the path.

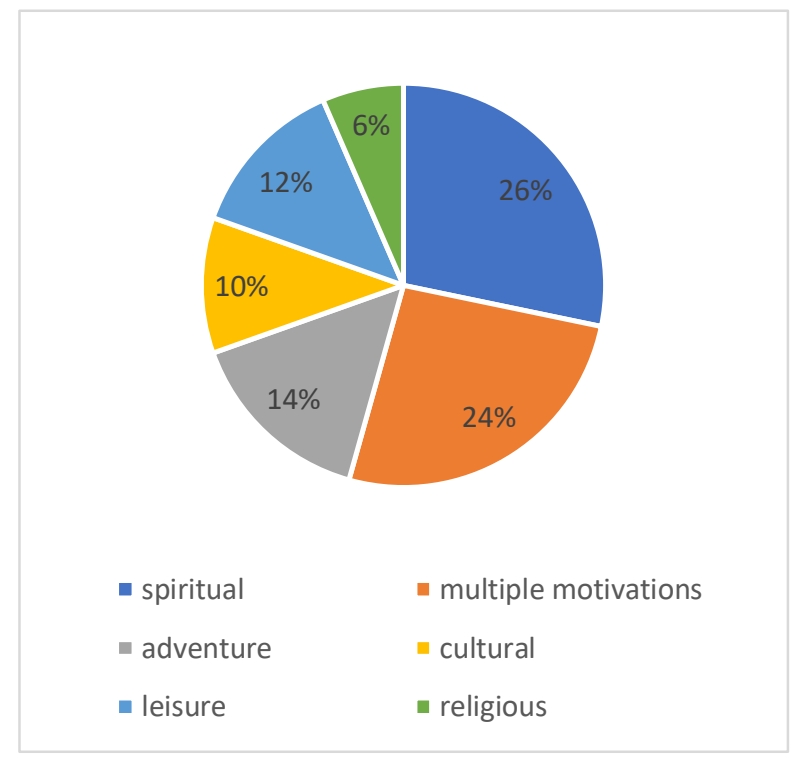

Fig 5. Motivations.

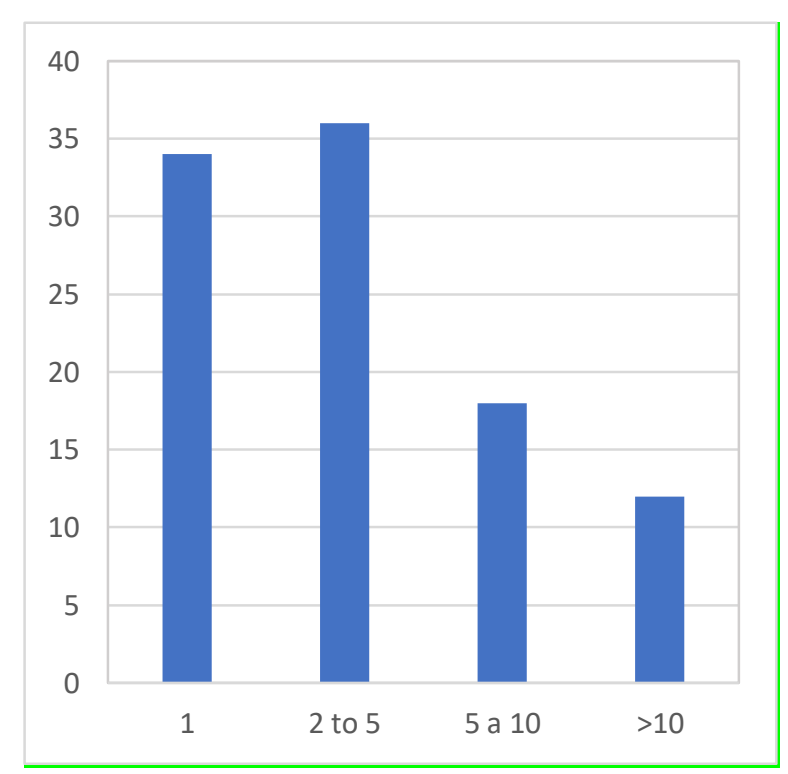

Fig 6. Days spent doing the Way.

Source: own preparation based on the interviews

As for the monetary expenses incurred, most of them did not spend large amounts of money, with daily expenses of up to $€ 10$ predominating, as shown in figure 7 .

In relation to the activities undertaken and the types of expenses, as shown in figure 8 , 48 respondents report that most of their expenses were in cafés, and 32 had expenses in 
restaurants for meals. Also 28 respondents indicated that they had expenses with accommodation and 12 with transport.

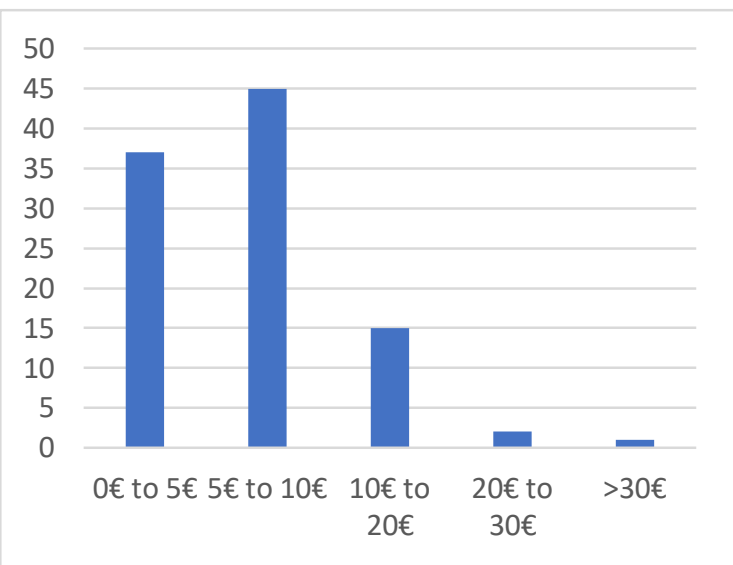

Fig 7. Monetary values spent.

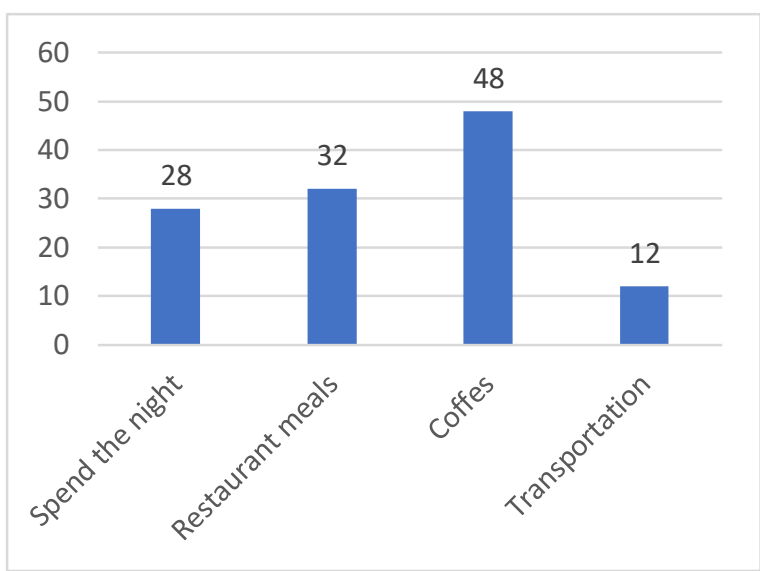

Fig 8. Activities and expenses in accommodation, board and transport.

Source: own preparation based on the interviews

In figure 9, other expenses that interviewees revealed to have are specified, predominantly the expenses with activities (42), where local tours, cycling, boating, among others, were mentioned; followed by the purchase of local and endogenous products (36), where souvenirs and the purchase of handicrafts are included. With less expression, the expenses with agricultural products and in commercial establishments were mentioned.

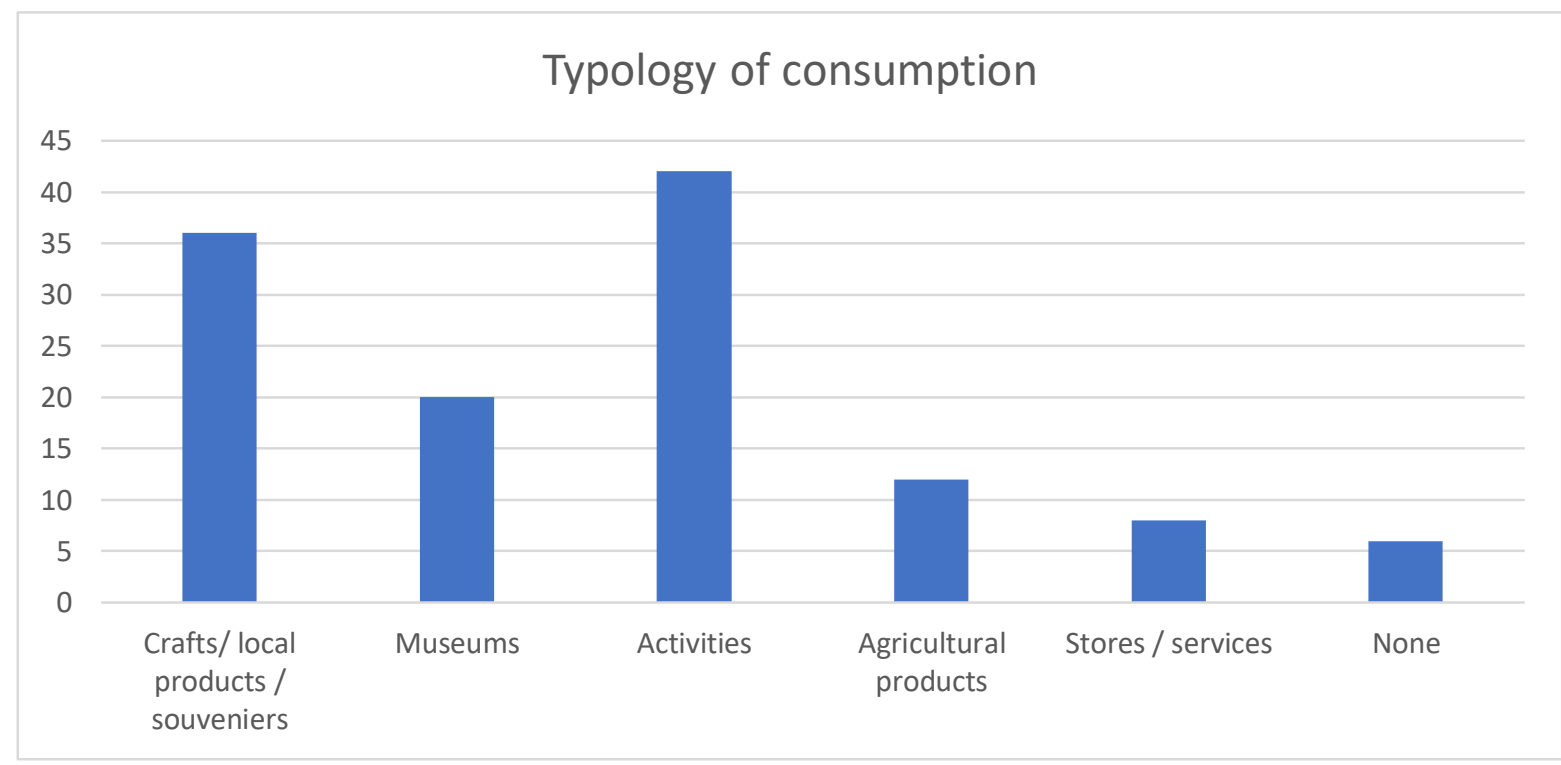

Fig 9. Remaining tipology of consumption. Source: own preparation based on the interviews

This indicator is relevant as it shows the importance that the tourist-pilgrims that follow the Ways have for the local community, especially in the purchase of local and endogenous products, thus generating income in these rural territories.

The last question focused on whether or not, after walking the Ways, they wanted to visit the Trásos-Montes and Alto Douro region again. $98 \%$ of them unanimously replied that they intended to return.

In a complementary way, the interviews carried out with technicians of tourism offices in the region are interconnected with the answers obtained in the surveys. In this sense, the technician of the Tourist Office of Vila Real indicates the creation of hostels, the adaptation of medium-sized 
hotel units by creating packages to receive pilgrims, and the emergence of new services such coffes shops, some restaurants and small grocery stores around the itineraries (technician of tourism, September 16, 2020, Vila Real);

From another perspective, "the conversion of these Ways into tourist-cultural routes allows them to be inserted in soft tourism, where the environmental component, the communities and rural landscapes and resources predominate. On the other hand, the valorisation of the historical and cultural heritage, namely the religious heritage linked to the Jacobean cult, has been the target of valorisation programmes in an attempt to complement the tourism offer of the region, where for example, churches have been opened due to the passage of pilgrims" (tourism technician, 18 September 2020, Mondim de Basto).

In Bragança, the tourism technician stated that the tourist-pilgrims who travel along the Silver Way stop for a period to visit the heritage and museums of the region, the parks, and gardens, which gives an environmental component to the route (tourism technician, 4 September 2020, Bragança).

These indicators show the importance of the passage of tourist-pilgrims who travel these paths and who are key agents in the development and dynamisation of these rural territories and their communities.

\section{Conclusions}

The inclusion of the Ways of Saint James which cross the region of Trás-os-Montes and Alto Douro in soft tourism, i.e. in a type of sustainable and environmental tourism occurs mainly due to two factors: the non-existent tourist massification that these routes present, as well as the fact that they are located in predominantly rural areas and far from major urban centres.

There are other facts that demonstrate the insertion of the paths in the so-called soft tourism:

- It is notorious that the Paths are travelled with spiritual and multiple motivations.

- Light means of transport, as they are done on foot and by bicycle.

- Although they generate a profitability considered average, it is clear that the expenses make it possible to dynamize the local commerce and the local products, namely the endogenous resources, which shows a possible development of the local communities.

- Outdoor activities and articulation with other environmental and natural resources.

- Very much linked to slow mobility.

Thus, we can see that the paths are part of soft tourism, due to sustainability, nature, landscapes, and the surrounding environment. In addition, it is a type of tourism that minimizes adverse environmental impacts.

The importance of the Ways for the development of these territories, combined with soft tourism, is particularly evidenced by the increase in the number of tourist-pilgrims passing along these pilgrimage routes. Moreover, they generate a multi-level development, i.e., it allows the conservation of the historical heritage; the revaluation of local traditions and products; it allows the revitalization of small rural local communities; it generates sustainable tourism and generates economic dynamism.

In short, this study allows us to demonstrate that the Ways of Saint James in Trás-os-Montes and Alto Douro have a set of characteristics of their own, making it go beyond its religious aspect to become a much more comprehensive resource and with multiplying effects in these rural territories.

\section{Acknowledgement}

This work is carried out within the scope of the Research Grant with the reference SFRH / BD / 136459/2018 attributed by FCT - Portugal. 
The Center for Transdisciplinary Studies for Development (CETRAD) is financed by national funds through FCT - Foundation for Science and Technology, I.P., under the project UIDB / 04011/2020.

Academic references

[1] Almeida, C. A. F. de (1968). Vias Medievais. I. Entre-Douro-e-Minho. Porto: author's edition.

[2] Ashley, S. L. (2014). Re-telling, re-cognition, re-stitution: Sikh heritagization in Canada. Cultura, 11(2), 39-58. DOI: 10.5840/cultura201411214.

[3] Balestrieri, M. \& Congiu, T. (2017). Rediscovering rural territories by means of religious route planning. Sustainability, 9(3), Art. 363. DOI: 10.3390/su9030363.

[4] Bambi, G., lacobelli, S., Rossi, G., Pellegrini, P. \& Barbari, M. (2019). Rural tourism to promote territories along the ancient roads of communication: case study of the rediscovery of the St. Francis's ways between Florence and La Verna. European Countryside, 11(3), 462474. DOI: 10.2478/euco-2019-0025.

[5] Bjorna, H. \& Aarsaether, N. (2010). Local government strategies and entrepreneurship. International Journal of Innovation and Regional Development, 2(1-2), 50 65. DOI: 10.1504/IJIRD.2010.029854.

[6] Bramwell, B. \& Lane, B. (1999). Editorial. Collaboration and Partnerships for Sustainable Tourism. Journal of Sustainable Tourism, 7(3-4), 179-181. DOI: $10.1080 / 09669589908667335$.

[7] Cohen, A. P. (1993). Culture as identity: an anthropologist's view. New literary history, 24(1), 195-209. DOI: $10.2307 / 469278$.

[8] Collins-Kreiner, N. (2010). Researching Pilgrimage: Continuity and transformations. Annals of Tourism Research, 37(2), 440-456. DOI: 10.1016/j.annals.2009.10.016.

[9] Cova, V., Bousquet, J., Claveau, C. \& Qazi Shabir, A. (2019). The changing dichotomy between the sacred and the profane: a historical analysis of the Santiago de Compostela pilgrimage. Journal of Management, Spirituality \& Religion, 16(1), 109-130. DOI: 10.1080/14766086.2018.1501415.

[10] Dentinho, T. \& Rodrigues, O. (2007). Os actores e as redes do desenvolvimento rural. In Dentinho, T. \& Rodrigues, O., eds., Periferias e Espaços Rurais: comunicações do II Congresso de Estudos Rurais Principia (pp. 231-240). Estoril: Princípia.

[11] d'Entremont, A. \& Lerga, J. T. (2019). From private devotion to universal phenomenon: The Way of Saint James in Spain, the case of Navarra. International Journal of Religious Tourism and Pilgrimage, 7(5), 11-23. DOI: 10.21427/38th-3e38.

[12] Duarte, A. C. F. (2016). Caminhos de Santiago: o Caminho Português como fator de desenvolvimento turístico no concelho de Barcelos. Porto: Universidade do Porto.

[13] Eusébio, C., Kastenholz, E. \& Breda, Z. (2014). Tourism and Sustainable Development of Rural Destinations: a stakeholders'view. Revista Portuguesa de Estudos Regionais, 36, 1321.

[14] Figueiredo, E. \& Oliveira Baptista, F., eds. (2011). Um rural cheio de futuros? Castro Verde: 100 Luz.

[15] Freitas, D. G., Justo, C. P. \& Samartim, R. (2021). Perceção e realidade dos impactos do Caminho Português interior a Santiago na atividade comercial da cidade de Chaves: Análise sobre parâmetros da economia, a interação, a identidade local e as políticas públicas. Rotur: revista de ocio y turismo, 15(1), 59-77.

[16] Gutiérrez Brito, J., ed. (2006). La investigación social del turismo. Perspectivas $y$ aplicaciones. Madrid: Thomson.

[17] Guiver, J. \& McGrath, P. (2017). Slow Tourism: Exploração de discursos. Dos Algarves: A Multidisciplinary e-Journal, 27, 11-34. DOI: 10.18089/DAMeJ.2016.27.1. 
[18] Krippendorf, J. (1982). Towards new tourism policies: The importance of environmental and sociocultural factors. Tourism management, 3(3), 135-148. DOI: 10.1016/02615177(82)90063-2.

[19] Ledo, A. P., Bonín, A. R. \& Iglesias, A. M. I. (2007). El turismo cultural como factor estratégico de desarrollo: el camino de Santiago. Estudios Geográficos, 48(262), 205-234. DOI: 10.3989/egeogr.2007.i262.11.

[20] Lois González, R. C. \& López, L. (2012). El Camino de Santiago: una aproximación a su carácter polisémico desde la geografía cultural y el turismo. Documents d'Anàlisi Geogràfica, 58(3), 459-479. DOI: 10.5565/rev/dag.6.

[21] Lois-González, R. C., Santos-Solla, X. M. \& Taboada-de-Zuniga, P., eds. (2014). New Tourism in the 21st Century: Culture, the City, Nature and Spirituality. Cambridge: Cambridge University Press.

[22] Long, N. (2005). Exploring local/global transformations: A view from anthropology. In Arce, A. \& Long, N., eds., Anthropology, Development and Modernities: exploring discourses, counter tendencies and violence (pp. 183-200). London: Routledge.

[23] Lourens, M. (2007). Route tourism: a roadmap for successful destinations and local economic development. Development Southern

Africa, 24(3), 475-490. DOI: $10.1080 / 03768350701445574$.

[24] Makuc, N. (2015). Fostering socio-economic development of rural areas through cultural and religious tourism: innovative solution for involvement of private sector. Firenze University Press.

[25] Merinero, R. (2011). Redes de actores y desarrollo turístico: estudio de casos en Portugal. Revista de análisis turístico,11, 9-21.

[26] Murray, M. \& Graham, B. (1997). Exploring the dialectics of route-based tourism: the Camino de Santiago. Tourism management, 18(8), 513-524. DOI: 10.1016/50261-5177(97)00075-7.

[27] Oliveira, L. D. (2012). Os Limites do Crescimento: 40 Anos Depois. Revista Continentes, (1), 72-96.

[28] Oliver, T. \& Jenkins, T. (2003). Sustaining rural landscapes: The role of integrated tourism. Landscape Research, 28(3), 293-307. DOI: 10.1080/01426390306516.

[29] Olsen, D. H. \& Trono, A., eds. (2018). Religious pilgrimage routes and trails: Sustainable development and management. Wallingford: $\mathrm{CABI}$.

[30] Padin, C. \& de Blas, X. P. (2015). Patrimonio y turismo sostenible en el Camino de Santiago: la gestión de las administraciones locales del itinerario francés en Galicia. PASOS. Revista de Turismo y Patrimonio Cultural, 13(6), 1413-1423.

[31] Pereiro, X. (2017). Turiperegrinos portugueses no Caminho Português Interior de Santiago de Compostela. Revista Turismo \& Desenvolvimento 27/28(1), 413-423. DOI: 10.34624/rtd.v1i27/28.8515.

[32] Pereiro, X. (2019). Tourism and Pilgrimage, Two Sides of the Same Currency: The Portuguese Inland Way of St. James. Cuadernos de Turismo, 43, 613-616.

[33] Pérez, C. M. (2015). Al andar se hace turismo: nuevas ruralidades en torno al Camino de Santiago. Aposta. Revista de Ciencias Sociales, 65, 131-150.

[34] Roget, F. M., Dominguez, M. N. C. \& Brea, J. A. F. (2018). O turismo como fonte de riqueza en Galicia: Análise dalgunhas experiencias. Revista Galega de Economía, 27(3), 65-80. DOI: 10.15304/rge.27.3.5437.

[35] Sánchez-Carretero, C., ed. (2015). Heritage, Pilgrimage and the Camino to Finisterre. New York: Springer.

[36] Seravalli, G. (2015). An introduction to place-based development economics and policy. Heidelberg: Springer. 
[37] Sharpley, R. \& Sharpley, J. (1997). Rural tourism. An introduction. Oxford: International Thomson Business Press.

[38] Slee, B., Farr, H. \& Snowdon, P. (1995). Soft tourism and rural development in Badenoch and Strathspey. Scottish Agricultural Economics Review, (8), 53-62.

[39] Slee, B., Farr, H. \& Snowdon, P. (1997). The economic impact of alternative types of rural tourism. Journal of Agricultural Economics, 48(1-3), 179-192. DOI: 10.1111/j.14779552.1997.tb01144.x.

[40] Snowdon, P., Slee, B. \& Farr, H. (2000). The Economic Impacts of Different Types of Tourism in Upland and Mountain Areas of Europe. In Godde, P. M., Price, M. F., Zimmermann, F. M., eds., Tourism and development in mountain regions (pp. 137-156). Wallingford: CABI.

[41] Sousa, L. C. D. (2014). Património como estratégia de desenvolvimento local: o caso de Arnelas, Crestuma e Lever [Mag. Theses]. Braga: Universidade do Minho.

[42] Terluin, I. (2003). Differences in economic development in rural regions of advanced countries: an overview and critical analysis of theories. Journal of Rural Studies, 19(3), 327344. DOI: 10.1016/S0743-0167(02)00071-2.

[43] Varga, A. (2017). Place-based, spatially blind, or both? Challenges in estimating the impacts of modern development policies: the case of the GMR policy impact modeling approach. International Regional Science Review, 40(1), 12-37. DOI: $10.1177 / 0160017615571587$.

\section{Other sources}

[44] Primitive way of St. James renovated with EU funding. European Commission (2020). Available at: https://ec.europa.eu/regional_policy/en/projects/spain/primitive-way-of-stjames-renovated-with-eu-funding.

[45] Eixo Atlântico (Ed.) (2015). Caminho de Santiago: Estudos dos traçados no Norte de Portugal. Porto: Eixo Atlântico e Xunta de Galicia.

[46] ESPON (2017). Territorial Cooperation for the future of Europe. Luxembourg: European Union. Available at: https://territorial-review.espon.eu/doc/ESPON_Territorial_Review.pdf.

[47] INE - Statistics of Portugal (2020). Available at: https://www.ine.pt/xportal/xmain?xpid=INE\&xpgid=ine_cont_inst\&INST=6251013\&xlang=pt.

[48] INE - Statistics of Portugal (2014). Typology of Urban Areas- TIPAU.

[49] Oficina del Peregrino (2020). Available at: https://oficinadelperegrino.com/. 